\title{
Phytomedicines for female infertility in Barpeta District of Assam, India
}

\author{
Vandana Singh $^{1}$, D. K. Bhattacharjya ${ }^{2}$ and Jyotchna Gogoi ${ }^{3}$ \\ ${ }^{1}$ Department of Sciences, Assam Down Town University, Panikhaiti, Guwahati - 781026, Assam, India \\ ${ }^{2}$ Postgraduate Department of Botany, M.C. College, Barpeta - 781301, Assam, India \\ ${ }^{3}$ Department of Biochemistry, Assam Down Town University, Panikhaiti, Guwahati - 781026, Assam, India \\ ${ }^{1}$ Corresponding Author, E-mail: vandana.singh22@gmail.com \\ [Received 20.05.2019; Revised 26.06.2019; Accepted 28.06.2019; Published 30.06.2019]
}

\begin{abstract}
The present study enlists a total of 25 plant species covering 18 families that are being used in 12 different formulations to cure female infertility. Out of the total 18 families recorded, Malvaceae comprises highest number of species followed by Combretaceae in preparation of the herbal medicines. Regarding plant parts used, bark was found to be used in majority of the formulations followed by leaves and seeds.
\end{abstract}

Key words: Female Infertility, Phyto medicines, Barpeta district, Assam

\section{INTRODUCTION}

Various species of plants used in herbalism are thought to have medicinal properties. For many centuries, plants have been the primary source of medicines. The ancient record evidencing their use by Indians, Chinese, Egyptians, Greeks, Romans and Syrians dates back to about 5000 years (Rabe \& Staden 1997). In India, it is reported that traditional healers use at least 2500 plant species and 100 species of plants serve as regular source of medicine (Pie 2001). There are around 400 families of flowering plants in the world of which at least 315 are represented the Indian flora (Sharma 2003).

Assam with its vast and with rich traditional ethno-botanical knowledge has huge potential and possibilities in the field of Phytomediciens (Kalita \& Phukan 2010). Some of these medicinal species have been extensively used in the Ayurvedic, Unani and other traditional alternative medicine systems since the time immemorial (Satyavati et al. 1987). Barpeta, like most districts of Assam, is also housing rich natural flora and ethno-medicinal plants. Barpeta district is situated in between $26^{\circ} 5^{\prime} \mathrm{N}$ to $26^{\circ} \mathrm{N}$ latitude and $90^{\circ} 39^{\prime}$ East to $91^{\circ} 17^{\prime}$ longitude and occupying an area of $3245 \mathrm{sq}$. $\mathrm{km}$. In ancient times, Barpeta was part of Kamapitha division of Kamarupa. In colonial and post-colonial times, it became a part of Kamrup district till 1983, when new district of Barpeta was curved out. The area enjoys tropical monsoon climate having two distinct seasons viz. Summer and winter (Bora \& Bhattacharjya 2009).

Female infertility refers to infertility in female humans. Infertility is caused by many reasons, including nutrition, diseases, and other malformations of the uterus. Infertility affects women from around the world, and the cultural and social stigma surrounding it varies. As per National Institute for Health and Care Excellence, UK (NICE) guidelines state that "A woman of reproductive age, who has not conceived after 1 year of unprotected vaginal 
sexual intercourse, in the absence of any known cause of infertility, should be offered further clinical assessment and investigation along with her partner". According to the World Health Organization (WHO), infertility can be described as the inability to become pregnant, maintain a pregnancy, or carry a pregnancy to live birth. Infertility can further be broken down into primary and secondary infertility. Primary infertility refers to the inability to give birth either because of not being able to become pregnant, or carry a child to live birth, which may include miscarriage or a stillborn child. Secondary infertility refers to the inability to conceive or give birth when there was a previous pregnancy or live birth (Jones 1998).

Causes or factors of female infertility can basically be classified regarding whether they are acquired or genetic or strictly by location. Although factors of female infertility can be classified as either acquired or genetic, female infertility is usually more or less combination of nature and nurture. A woman's fertility is affected by her age. The average age of a girl's first period is $12-13$ years but a woman's fertility peaks in the early and mid-20s, after it starts to decline with this decline being accelerated after age 35. A large number of all fertility cases are a result of woman either being underweight or overweight. There are many genes where mutation causes female infertility.

Many researchers, round the world worked on the traditional medicines to cure female infertility and other gynaecological disorders including Lukhoba \& Siboe (2008), Bone et al. (1990), Khan \& Khan (2003), Panduranga et al. (2011) Raut et al. (2012), and Sahu (2011). In North-east India workers like Jain \& Borthakur (1980), Barua et al. (1999), Choudhury et al. (2011), Das et al. (2007), Sarma et al. (2001, 2002, 2006), Bhattacharjya (2008, 2012), Das et al. (2009), Sarkar \& Das (2010, 2011), Borah \& Bhattacharjya (2009), Singh \& Bhattacharjya (2014), Lepcha et al. (2011), Tiwari et al(1978), and Lukhoba \& Siboe (2008), have made valuable contribution. The present study is an attempt to focus on the phytomediciens and their use against female infertility in Barpeta districts of Assam.

\section{METHODOLOGY}

Ethnobotanical surveys were undertaken for more than one year 2016 to 2018 in 24 interior rural pockets of Barpeta district to know most prevalent gynaecological disorders among women and to prepare a list of well-known Vaids or medicine men from different communities including Koch-Rajvanshi, Nepali, Assamese and Bengali etc. Before the start of the survey mandatory PIC was taken from the informants. During oral interviews with local healers or aids, specific questions were asked according to the prepared questionnaires and the information supplied by the informants were taken to the field for the collection of plants for voucher specimens (Beer \& Wyk 2011; Raut et al. 2012; Mesfin et al. 2013; khan et al. 2014). Each medicinal practice was cross checked with at least $2-3$ informants. Then Voucher specimens were collected and processed following Jain \& Rao (1977) and identified by matching already existed herbarium of M.C. college then deposited in the Herbarium of the postgraduate Department of Botany, MC College, Barpeta, Assam. Scientific names were authenticated by consulting the website www.theplantlist.org.

\section{RESULT}

The present study enlists a total of 25 angispermic species of plants covering 18 families. These plant species are being used in 12 different formulations to cure female infertility (Table 1). Table 1 includes scientific names of the plant species grouped according to the formulations used, followed by vernacular name, Family, plant part used, methods of preparation and dose of medicine used by the local people of Barpeta district of Assam. Out of the 
84 Phytomedicines for female infertility in Barpeta District

total 18 families, Malvaceae and Combretaceae comprises of highest number of plant species ( $5 \mathrm{spp}$. each.) followed by $3 \mathrm{spp}$. by Moraceae and Solanaceae each in preparation of the herbal recipes (Figure 1). Out of the plant parts used, bark was found to be used from majority of the formulations ( 10 formulations) followed by leaves ( 8 formulations) and seeds (4 formulations) (Figure 2).

Table 1. Ethnoboatnical treatment for female infertility in Barpeta district of Assam

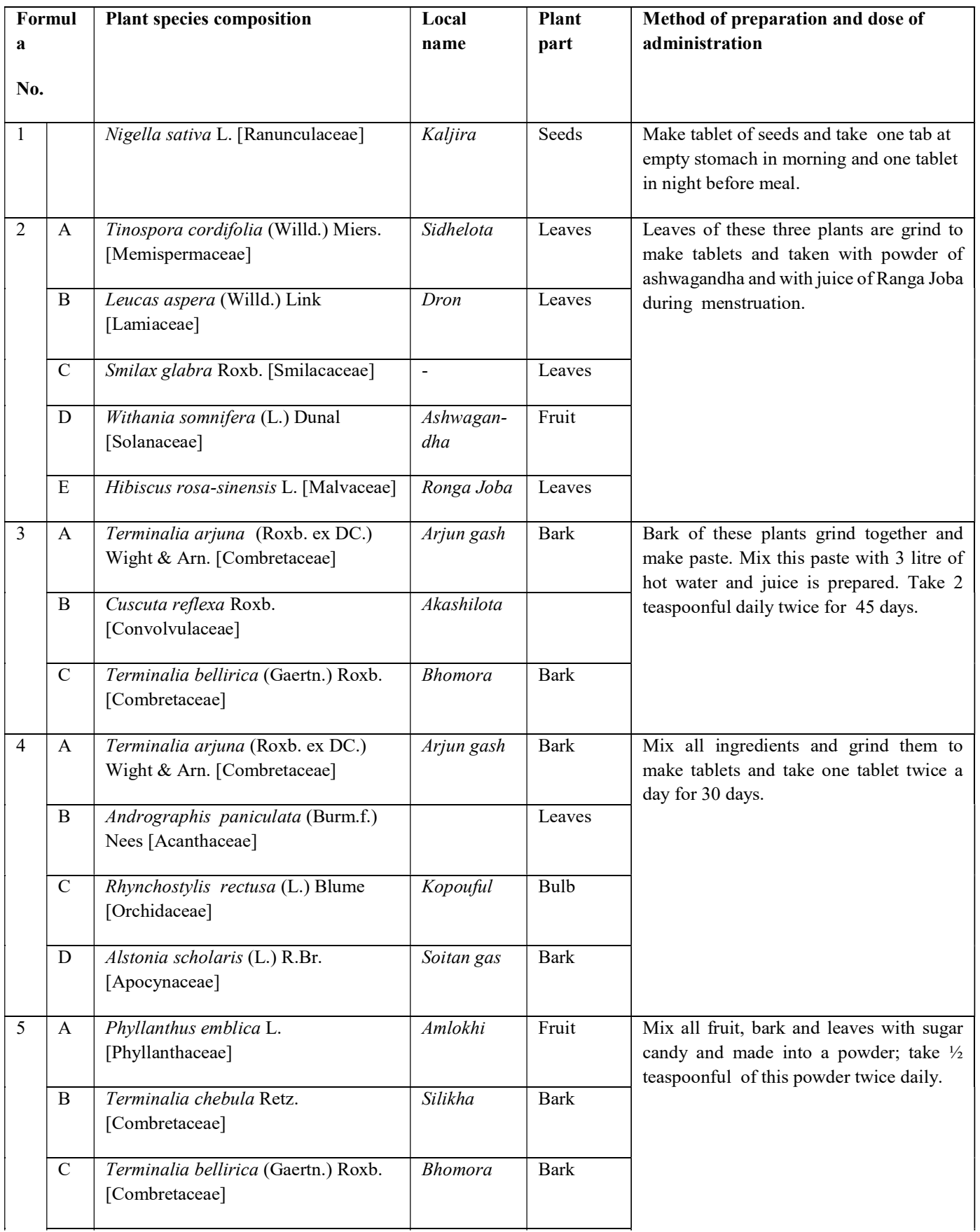




\begin{tabular}{|c|c|c|c|c|c|}
\hline & $\mathrm{D}$ & $\begin{array}{l}\text { Hemidesmus indicus (L.) R. Br. ex } \\
\text { Schult. [Apocynaceae] }\end{array}$ & Anantaful & Leaves & \\
\hline \multirow[t]{4}{*}{6} & $\mathrm{~A}$ & $\begin{array}{l}\text { Cynodon dactylon (L.) Pers. } \\
\text { [Poaceae] }\end{array}$ & Duburibon & Leaves & \multirow{4}{*}{$\begin{array}{l}\text { All raw materials are crushed and their } \\
\text { juice should be separated and with the } \\
\text { solid part mix til into it and make pills; } \\
\text { mix a pill in half cup of juice extracted and } \\
\text { take twice daily for } 7 \text { days. }\end{array}$} \\
\hline & $\mathrm{B}$ & Ficus religiosa L. [Moraceae] & Ahatgash & Leaves & \\
\hline & $\mathrm{C}$ & $\begin{array}{l}\text { Artocarpus heterophyllus Lam. } \\
\text { [Moraceae] }\end{array}$ & Kathal & $\begin{array}{l}\text { New } \\
\text { flower }\end{array}$ & \\
\hline & $\mathrm{D}$ & Sesamum indicum L. [Pedaliaceae] & Til & Seed & \\
\hline 7 & $\mathrm{~A}$ & $\begin{array}{l}\text { Artocarpus heterophyllus Lam. } \\
\text { [Moraceae] }\end{array}$ & Kathal & $\begin{array}{l}\text { Infloresce } \\
\text { nce axis }\end{array}$ & $\begin{array}{l}\text { Dried Inflorescence axis of species grind } \\
\text { with rice and make pill. One pill after } \\
\text { dinner for } 7 \text { days. }\end{array}$ \\
\hline 8 & $\mathrm{~A}$ & Abroma augusta (L.) L.f. [Malvaceae] & Utkamal & Root & $\begin{array}{l}\text { Past of root take } 1 \text { teaspoonful twice for } 3 \\
\text { to } 4 \text { days. }\end{array}$ \\
\hline \multirow[t]{2}{*}{9} & $\mathrm{~A}$ & $\begin{array}{l}\text { Zingiber officinale Roscoe } \\
\text { [Zingiberaceae] }\end{array}$ & Ada & Bulb & \multirow[t]{2}{*}{$\begin{array}{l}\text { Take seed of jalum with juice of Ada once } \\
\text { daily for } 7 \text { days. }\end{array}$} \\
\hline & $\mathrm{B}$ & Piper longum L. [Piperaceae] & Jaluk & Seed & \\
\hline \multirow[t]{2}{*}{10} & $\mathrm{~A}$ & Abroma augusta (L.) L.f. [Malvaceae] & Utkamal & Stem & \multirow{2}{*}{$\begin{array}{l}\text { Take stem and seeds and crush them and } \\
\text { made into pills; take } 1 \text { pill once daily in } \\
\text { empty stomach for } 3 \text { months. }\end{array}$} \\
\hline & $\mathrm{B}$ & Piper longum L. [Piperaceae] & Jaluk & Seeds & \\
\hline \multirow[t]{4}{*}{11} & $\mathrm{~A}$ & Bombax ceiba L. [Malvaceae] & Simala & Bark & \multirow[t]{4}{*}{$\begin{array}{l}\text { Bark of all plants crushed to make pill; } \\
\text { take one pill daily in empty stomach. }\end{array}$} \\
\hline & $\mathrm{B}$ & Mangifera indica L. [Anacardiaceae] & Aam & Bark & \\
\hline & $\mathrm{C}$ & $\begin{array}{l}\text { Litsea glutinosa (Lour.) C.B. Rob. } \\
\text { [Lauraceae] }\end{array}$ & Bhagnala & Bark & \\
\hline & $\mathrm{D}$ & Sida rhombifolia L. [Malvaceae] & Saruboiral & Bark & \\
\hline \multirow[t]{2}{*}{12} & $\mathrm{~A}$ & Solanum torvum Sw. [Solanaceae] & Konthagiri & Root & \multirow[t]{2}{*}{$\begin{array}{l}\text { Root juice of both plants take daily in } \\
\text { empty stomach. }\end{array}$} \\
\hline & $\mathrm{B}$ & Datura stramonium L. [Solanaceae] & Datura & Root & \\
\hline
\end{tabular}

\section{DISCUSSIONS}

The families Malvaceae, Combretaceae, Solanaceae and Moraceae etc. along with others have contributed much of the species towards the preparation of herbal recipes in treating the Infertility problems. Out of all the plant parts used in the preparation, leaves, roots and barks are of maximum use in the herbal formulations. The study indicates that wide spectrum of remedies are used by local healers for women to regulate the Infertility issues. It is however very important to collect correct part of plant during collection since a specific part may be toxic whilst another may have no harmful effect due to a differences in the concentration of active ingredients in different parts of the plants. Dosage form as well the method of preparation and administration are very important (Nadkarini 2001).Most of the medicinal plants are prepared as either powders, infusions or decoctions which are taken orally. 


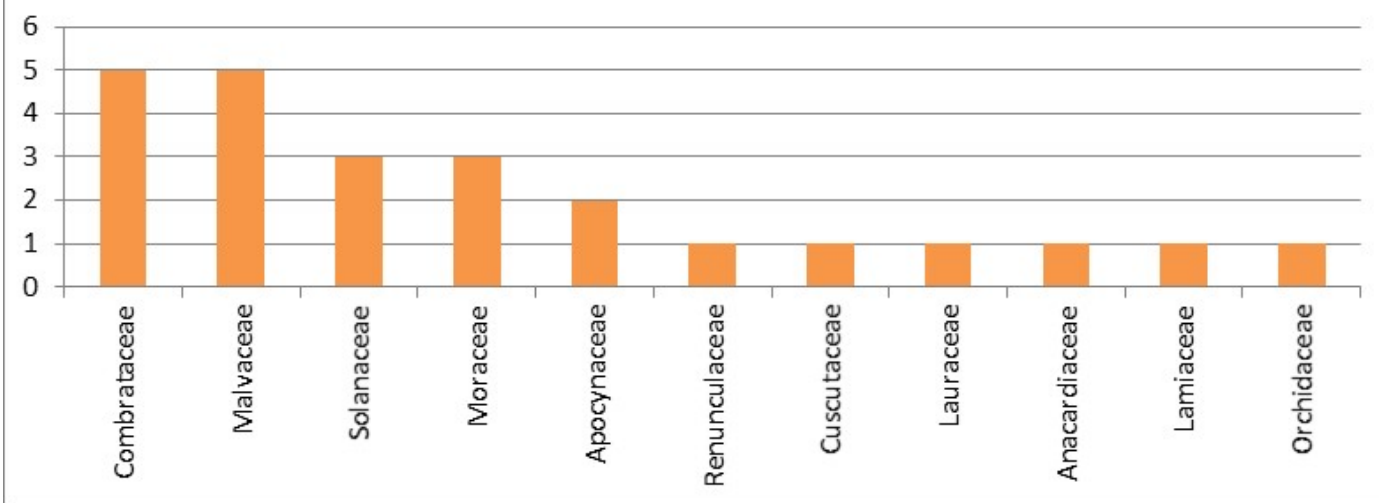

Figure 1. Family wise distribution of species used in different formulations

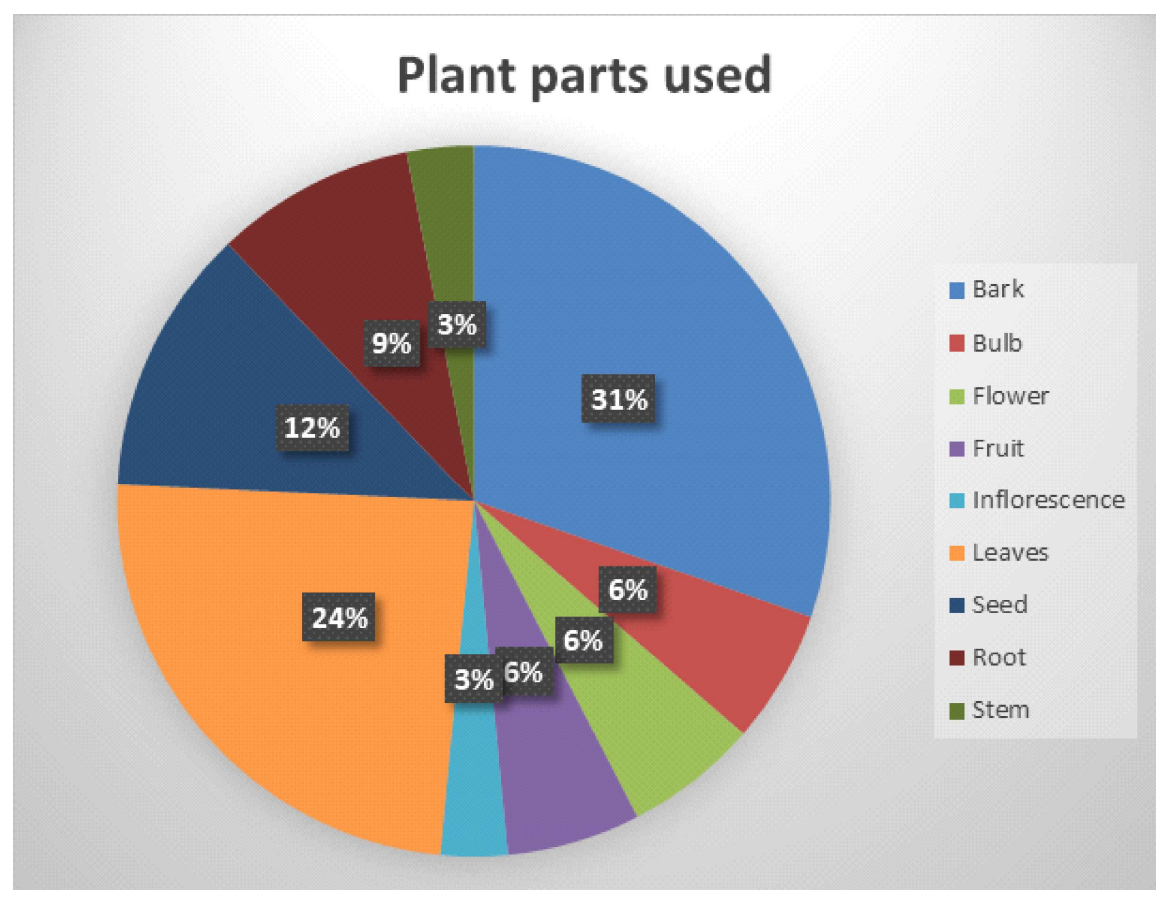

Figure 2. Percentage frequency of different plant parts used in different formulations

The study indicates that wide spectrum of remedies are used by local healers for women to regulate the Infertility issues and are effective in many cases. The study also shows light on, how young generation is not intrested in learning the uses of these phytomedicines, so it becomes very important to document this knowledge before it get lost forever. Auther feels the requirement of biochemical analysis of plant species to find out the active compounds, which are responsible for curing the problem. This will establish a link between phytomedicines and their effect against particular problem. This will help in discovering new drugs in future. Author also feels the need of conserving important plant species by preventing over exploitation and by commercial cultivation of the same. 


\section{Acknowledgements}

Authors are grateful to the local villagers including Sayed Basti Ali from Kella, Dinanath Das from Keotkuchi, Gopesh Das from Gandhi Nagar, Sachindra Barman from Pakabetbari and many more who helped us by sharing their valuable phytomedicinal knowledge during the field trips.

\section{LITERATURE CITED}

Barua,K.N.; Barua, I.C. \& Das M. 1999. Ethnobotany of Rajbonshis of Assam.J.Econ Taxon. Bot. 23(2): 609 - 614.

Beer, Josef de \& Wyk, Ben-Erik van.2011.doing an Ethnobotanical Survey in the life Sciences Classroom. The American Biology Teacher.73(2): 90 - 97.

Bhattacharjya, D.K.; Sarma, S.K.: Boarah, P.C. \& Kar, A.2008.Notes on select herbal treatments of the common people in Barpeta District, Assam. J. Adv. Pl. Sci. 4(1\&2): $69-73$.

Bhattacharjya, D.K.; Sarma.H.; Kar, A. \& Patowary, K.N.2012. Notes on herbal treatment practiced by the people of fringe villages of Manas National Park, India. Indian J. Trad. Knowl. 7(3): 501 - 504.

Bone, M.E.; Wilkinson, D.J.; Young, J.R.; McNeil, J. \& Sharlton, S. 1990. Ginger-root - a new antiemetic. The effect of ginger root on postoperative nausea and vomiting after major gynaecological surgery. Anesthesia. 45(8): $669-671$.

Bora, P.C. \& Bhattacharjya., D.K. 2009. Treatment of some female diseases by tribal people under Gobardhana block of Barpeta district of Assam, India. Pleione, 3(2): 148 - 151.

Choudhury, N.; Mahanta, B. \& Kalita, J. 2011. An ethnobotanical survey on medicinal plants used in reproductive health related disorders in Rangia subdivision, Kamrup district, Assam. Intn. J. Sci. Adv. Tech. 1(7): $154-159$.

Das, A.P.; Ghosh, C.; Sarkar, A. \& Biswas, R. 2007. Ethnobotanical Studies in India with Notes on Terai-Duars and Hills of Darjiling and Sikkim. NBU J. Pl. Sci. 1: $67-83$.

Das, S.; Khan, M.L.; Rabha, L. \& Bhattacharjya, D.K. 2009. Ethnomedicinal Plants of Manas National Park, Assam, Northeast India. Indian J. Trad. Knowl. 8 (4): 514 - 517.

Jain, S.K. \& Borthakur, S.K. 1980. Ethnobotany of the Mikiris of India. Econ. Bot. 34(3): $264-272$.

Jain,S.K. \& Rao, R.R.1977. A Handbook of field and Herbarium Method. Today \& Tomorrow's Printers and Publishers, New Delhi.

Jones; Llewellyn, D.L 1998. Every woman: Agynecological guide for life. Penguin Books Limited, New York.

Kalita, D. \& Phukan, B. 2010. Some Ethnomedicines used by the Tai Ahom of Dibrugarh district, Assam, India. Indian J. Nat. Prod. Resrc. 1(4): 507 - 511.

Khan, A.V. \& Khan, A.A. 2003. Herbal abortifacients used by folk people of some districts of western Uttar Pradesh. J. Nat. Remed. 3 (1): 41 - 44.

Khan, I.; Naser, M.; Elsalam, Abd; Hassan, F.; Akash, T.; Ullah, R.\& Adnan, M. 2014. Application of Ethnobotanical Indices on the uses of Traditional Medicines against common Diseases, Evidence-Based Complementary and Alternative Medicine. Article ID 635371,21 pages http://dx.doi.org/10.1155/2014/635371. 
Lepcha, S.R. \& Das, A.P. 2011. Ethno-medicobotanical exploration along the international borders to Tibet Autonomous Region of China and the kingdom of Bhutan with special reference to the Pangolakha Wildlife Sanctuary, East Sikkim, India. In: C. Ghosh \& A.P. Das (eds.), Recent Studies in Biodiversity and Traditional Knowledge in India. Sarat Book House, Kolkata. Pp. 257 - 270.

Lukhoba, C.W. \& Siboe, G.M. 2008. Use of Ethnobotanical Data in the Search for and Identification of Potential Drug Plants. E. C. Afr. J. Pharm. Sci.11: $43-48$.

Mesfin,K.; Tekle, G. \& Tesfay, T. 2013. Ethnobotanical Study of Traditional Medicinal Plants used by Indigenous People of Gemad District, Northern Ethiopia. J. Med. Pl, Stud. 1(4): 97 - 107.

Nadkarini, K.M. 2001. Indian plants and drugs with their medicinal properties and uses. Asiatic Publishing House, New Delhi.

Pie, S.J. 2001. Ethnobatanical approaches of traditional medicine and technique. Today and Tomorrows Publication, Dehradun.

Panduranga, R.M.; Prasanthi, S. \& Redidi, T.V.V. 2011. Medicinal plants in folk medicine for women's diseases in use by Konda Reddis. Indian J. Trad. Knowl. 10(3): 563 - 567.

Rabe,T. \& Staden, J.V. 1997. Antibacterial activity of South African plants used for medicinal purposes. J. Ethnopharmacol. 56: $81-87$.

Raut, S.; Raut, S.; Sen, S.K.; Satpathy, S. \& Pattnaik, D. 2012. An Ethnobotanical Survey of Medicinal Plants in Semiliguda of Koraput District, Odisha, India. Bot. Res. Intern. 5(4): $97-107$.

Sahu, P.K. 2011. Plants used by Gond and Baiga women in Ethnogynaecological disorders in Achanakmar Wildlife Sanstuary, Bilaspur, CG. J. Pharm. Life Sci. 2(2): 559 - 561.

Sarkar, A. \& Das, A.P. 2010. Ethnobotanical formulations for the treatment of Jaundice by the Mech tribe in Duars of West Bengal. Indian J. Trad. Knowl. 9(1): $134-136$.

Sarkar, A. \& Das, A.P. 2011. Plants used in contact therapy by Mech tribe in Duars of West Bengal, India. In: C. Ghosh \& A.P. Das, Recent Studies in Biodiversity and Traditional Knowledge in India. Sarat Book House, Kolkata. Pp. 311 - 314.

Sarma, S.K.; Bhattacharjya, D.K. \& Devi, B. 2001. Medicinal plants used by Bodo tribe of Nalbari district in Assam. Ethnobotany. 13: 135 - 139.

Sarma, S.K.; Bhattsacharjya, D.K. \& Devi, B. 2002. Traditional use of herbal medicines by Madahi tribe of Nalbari district of Assam. Ethnobotany. 14: 103 - 111.

Sarma, S.K.; Devi, B. \& Bhattacharjya, D.K. 2006. Ethnomedicinal uses of plants by the Sarania tribe of Nalbari district of Assam. J. Econ. Taxon. Bot. 30: 133 - 139.

Sharma R. 2003. Medicinal Plants of India - An Encyclopedia. Daya Publishing House, New Delhi.

Satyavati, G.V.; Gupta, A.K. \& Tondon, N. 1987. Medicinal Plants of India. Indian Council of Medical Research, New Delhi. India.

Singh,V. \& Bhattacharjya, D.K. 2014. Traditional phytomedicinal practices against lrucorrhoea in the Barpeta district of Assam,India. Pleione 8(2): 353 - 360.

Tiwari, K.C.; Majumdar,R. \& Bhattacharjee, S. 1978. Some medicinal plants from District Tirap of Arunachal Pradesh. Indian J. Pharm.Sci. 40: 206 - 208. 